\title{
Adiponectin Correlates in Malaysians: A Comparison of Metabolic Syndrome and Healthy Respondents
}

\author{
Mohd Aznan Md Aris ${ }^{1,2}$, Muhammad Muzaffar Ali Khan Khattak,3,4,*, Zamzila Abdullah ${ }^{5}$, Razman Mohd Rus ${ }^{6}$, \\ And Samsul Draman ${ }^{1}$ \\ ${ }^{1}$ Department of Family Medicine, Kulliyyah of Medicine, International Islamic University Malaysia, International Islamic University, \\ Malaysia, Jalan Sultan Ahmed Shah, Bandar Indera Mahkota Kuantan, Pahang Darul Makmur, MALAYSIA \\ ${ }^{2}$ Non Communicable Diseases Research Unit, Kulliyyah of Medicine, International Islamic University Malaysia (IIUM) Jalan Sultan \\ Ahmad Shah, Bandar Indera Mahkota, Kuantan, Pahang Darul Makmur; Malaysia. \\ ${ }^{3}$ Department of Nutrition Sciences, Kulliyyah of Allied Health Sciences, International Islamic University, Malaysia, Jalan Sultan \\ Ahmed Shah, Bandar Indera Mahkota Kuantan, Pahang Darul Makmur, MALAYSIA \\ ${ }^{4}$ International Institute for Halal Research and Training (INHART), Kulliyyah of Engineering, International Islamic University \\ Malaysia, Kuala Lumpur, MALAYSIA \\ ${ }^{5}$ Department of Basic Health Sciences, Kulliyyah of Medicine, Jalan Sultan Ahmed Shah, Bandar Indera Mahkota Kuantan, Pahang \\ Darul Makmur, MALAYSIA \\ ${ }^{6}$ Department of Community Medicine, Kulliyyah of Medicine, Jalan Sultan Ahmed Shah, Bandar Indera Mahkota Kuantan, Pahang \\ Darul Makmur, MALAYSIA \\ *Corresponding author: mkbiol@yahoo.com
}

Received September 11, 2014; Revised December 15, 2014; Accepted December 21, 2014

\begin{abstract}
Several studies have demonstrated that adiponectin has strong association with metabolic syndrome and its factors like obesity, insulin resistance, type 2 diabetes, dyslipidemia and coronary artery disease. A total 152 subjects were registered in this study. Among the respondents 76 were with metabolic syndrome (based on the criteria of the International Diabetes Federation (IDF) world-wide definition) and another 76 matching healthy respondents. The factors which were studied for possible differences and association include central obesity (body mass index (BMI) \& waist circumference (WC), hypertension (systolic blood pressure (SBP), diastolic blood pressure (DBP), dyslipidemia (total cholesterol (Tc), high density lipoprotein Cholesterol (HDL-c), low density lipoprotein Cholesterol (LDL-c), Triglyceride (TG) and Adiponectin (AD), fasting plasma glucose and history of smoking. The data collected was statistically analyzed using SPSS statistical software version 12.0. Two tests were performed including paired t-test and Pearson correlation analysis. The collected data revealed some interesting differences for the healthy and metabolic syndrome respondents. There were significant $(\mathrm{P}<0.01)$ differences for central obesity and hypertension. There were also significant $(\mathrm{P}<0.01, \mathrm{P}<0.1, \mathrm{P}<0.01)$ differences for TG, HDL and fasting plasma glucose. More importantly, $\mathrm{AD}$ concentration was significantly $(\mathrm{P}<0.05)$ higher in normal healthy respondents. The AD showed strong negative association $(r=-2.91, P<0.001)$ with FBG and positive association ( $r$ $=2.89, \mathrm{P}<0.001$ ) with HDL-c. The present study provides baseline information on the predication of metabolic syndrome in Malaysian population.
\end{abstract}

Keywords: adiponectin, abdominal obesity, metabolic syndrome, hypertension, dyslipidemia

Cite This Article: Mohd Aznan Md Aris, Muhammad Muzaffar Ali Khan Khattak, Zamzila Abdullah, Razman Mohd Rus, and And Samsul Draman, "Adiponectin Correlates in Malaysians: A Comparison of Metabolic Syndrome and Healthy Respondents.” American Journal of Clinical Medicine Research, vol. 2, no. 6 (2014): 106-110. doi: 10.12691/ajcmr-2-6-1.

\section{Introduction}

According to the National Institute of Health (NIH) metabolic syndrome (MS) also called as dysmetabolic syndrome, hypertriglyceridemic waist, insulin resistance syndrome, obesity syndrome and Syndrome X. Whatever the name is it is often associated with abdominal obesity (AB) (visceral obesity) (OB). Indirectly, MS is the risk of having increased mortality and morbidity due to coronary artery diseases (CAD). Etiologically, it is closely associated with insulin resistance [1]. According to the definition of the International Diabetes Federation (IDF), for subjects to be defined as having the MS, must have visceral obesity plus any two of the four additional factors as shown in the Table 1 [2]. Clinically it has been demonstrated that LDLlowering therapy can reduce major coronary events and coronary mortality [3]. A secondary target for the prevention of CAD after cholesterol-lowering is the management of MS which include abdominal obesity, dyslipidemia, glucose intolerance and hypertension. Although genetic factors, excess body fat particularly abdominal or visceral obesity are caused by over nutrition 
and physical inactivity $[3,4,5,6]$. Recent research studies indicate that adipose tissues produce various bioactive peptides called as adipokines which are believed to possess hormones like activities. The dysregulation of these adipokines in abdominal obesity may precipitate in the development of the metabolic syndrome [7,8,9]. Why adiponectin was chosen in this particular study? The lack of availability of adiponectin is considered key marker among the adipokines in the pathogenesis of metabolic syndrome $[10,11,12,13]$. Several studies have demonstrated that the adiponectin concentration in the blood is a useful predictor which exhibits stronger association with metabolic syndrome factors such as its decrease in obesity [14], insulin resistance [15], type 2 diabetes [16,17,18,19], dyslipidemia [20] and coronary artery disease [16,21]. Conversely, weight loss [22] and pharmacological improvement of insulin sensitivity [23] are associated with increased adiponectin levels. Lack of adiponectin results in an increased susceptibility to diet-induced insulin resistance [24]. Treatment of animals with adiponectin improved insulin resistance and other metabolic abnormalities associated with obesity and lipoatrophy $[25,26]$.

Table 1. International Diabetes Federation Metabolic Syndrome World-wide Definition

\begin{tabular}{|c|c|}
\hline Central Obesity & Waist circumference -plus any two of the following \\
\hline Raised triglycerides & $\begin{array}{l}\geq 1.7 \mathrm{mmol} / \mathrm{l}(150 \mathrm{mg} / \mathrm{dl}) \text { or specific treatment } \\
<1.03 \mathrm{mmol} / \mathrm{l}(40 \mathrm{mg} / \mathrm{dl} \text { in males })\end{array}$ \\
\hline Reduced HDL-Cholesterol & $\begin{array}{l}<1.29 \mathrm{mmol} / \mathrm{l}(50 \mathrm{mg} / \mathrm{dl} \text { in females }) \\
\text { or specific treatment }\end{array}$ \\
\hline Raised blood pressure & $\begin{array}{l}\text { Systolic } \geq 130 \mathrm{mmHg} \\
\text { or Diastolic } \geq 85 \mathrm{mmHg} \\
\text { or treatment of previously diagnosed hypertension }\end{array}$ \\
\hline Raised fasting plasma glucose & $\begin{array}{l}\text { Fasting plasma glucose } \geq 5.6 \mathrm{mmol} / \mathrm{l}(100 \mathrm{mg} / \mathrm{dl}) \text { or previously diagnosed Type } 2 \text { diabetes. } \\
\text { If }>5.6 \mathrm{mmol} / \mathrm{l} \text { or } 100 \mathrm{mg} / \mathrm{dl} \text {, oral glucose tolerance test is strongly recommended but is not necessary to define } \\
\text { presence of the syndrome. }\end{array}$ \\
\hline
\end{tabular}

Adiponectin concentration in the blood is positively correlated to HDL-c concentration but negatively to insulin concentration [30]. Furthermore, the concentration in blood is reduced in obese and type 2 diabetes [31]. Adiponectin possibly has anti-atherogenic, insulin sensitizing, lipid oxidizing and vasodilating effects [33,34]. Plasma adiponectin is a useful biomarker for metabolic syndrome [35]. Therefore, this was an effort to study the association between adiponectin concentrations with the defined risk factors of metabolic syndrome in Malaysian population.

\section{Methods}

A Cross sectional comparative study was carried out in seven different polyclinics around Kuantan district which is the state capital of Pahang Malaysia. A total of 152 subjects were registered in this study. Among the respondents 76 were with metabolic syndrome (based on the criteria of the International Diabetes Federation (IDF) world-wide definition) and another 76 were matching healthy (control) respondents. The control group was selected from healthy individuals matching to the nearest possibility in particular in terms of age. According to World Health Organization (WHO) [36], health is a state of complete physical, mental and social well-being and not merely the absence of disease or infirmity. Apart from age, the other matching factors included were gender, races and income etc. An informed consent was obtained from all respondents and were free to participate in this study. Prior data collection, the study protocol was approved from the relevant health authorities of the District Kuantan of Pahang state and the International Islamic University Malaysia Research Ethical Committee (IREC) which is a recognized body of the Ministry of Health, Government of Malaysia. Adult population aged 20 years and above who attend to Polyclinics Community in Kuantan during the study period for health examination. The subjects were randomly selected from those who visited the primary care clinics. All individuals who were consented and fulfilled the criteria were included in the study. Participants were included and considered suitable for inclusion in this study group if fulfilled the criteria of metabolic syndrome described by IDF as mentioned earlier [28]: Central obesity (ethnicity specific): waist circumference (WC) $\geq 90 \mathrm{~cm}$ (Asian male) or $\geq 80 \mathrm{~cm}$ (Asian female) and two or more factors as indicated in the Table 1 . The participants were physically examined and some of the anthropometrics namely height, weight, waist circumference measured to the closest possible measurements with appropriate measuring tools along with some demographic information and of course blood pressure was recorded as well. Furthermore, the patients and the healthy respondents were requested to make an appointment for bloods sampling after overnight fasting. The collected blood was analyzed for serum lipid profile, serum adiponectin and fasting blood plasma glucose (FBG) test using appropriates commercial kits. The collected data was statistically analyzed by using SPSS statistical software version 15.0 for Windows using One-way ANOVA, Student t-test and Pearson correlation analysis. The differences were considered as significant at $95 \%$ confidence interval $(\mathrm{p}<0.05)$.

\section{Results}

The mean age of the respondents was $51 \pm$ years majority of Malay ethnicity. Most of them were nonsmoker (77.6\%) and had history of hypertension (51\%) and diabetes mellitus (46.4\%) with a mean waist circumference of $89 \pm \mathrm{cm}$ and mean weight of $66.6 \pm \mathrm{kg}$. Demographically, as indicated in the Table 2, the mean age of the MS respondents was $54 \pm$ years old while the non-MS group was $48 \pm$ years old. The number of current smokers in the MS group was less than in the non-MS (28 smokers and 06 smokers) as indicated in the Table 2.

Looking at the anthropometric indices it was noted that the BMI and WC were significantly $(\mathrm{P}<0.001)$ lower in the Non-MS respondents compared to MS respondents. Similarly, the blood pressure both systolic and diastolic were significantly $(\mathrm{P}<0.001)$ lower in the Non-MS respondents compared to MS respondents (Table 3). On 
overall the body weights, heights and BMI were significantly associated with adiponectin concentration (Table 5). The blood plasma analysis of the respondents are shown in the Table 4 which reveals that FBG concentration was significantly $(\mathrm{P}<0.001)$ lower in the Non-MS respondents compared to MS respondents and surprisingly the TC \& LDL-c were not different among the two groups of respondents. However, there seems to be a varied ratio of the cholesterol fractions which is evident from the concentration of HDL-c which was significantly $(\mathrm{P}<0.001)$ higher in the Non-MS respondents than the MS respondents. Triglyceride concentration in the circulation seems to be also significantly $(\mathrm{P}<0.05)$ lower in the Non-MS respondents compared to MS respondents. When the blood sample were assessed for AD it appears to be significantly $(\mathrm{P}<0.05)$ higher in the Non-MS respondents than the MS respondents (Table 4). The AD concentration was compared between MS and Non MS respondents using t-test for age, gender and smoking. These results suggest that age, gender and smoking do not affect $\mathrm{AD}$ concentration both in MS and non MS respondents Furthermore, Pearson correlation analysis was carried out to predict any possible association between the $\mathrm{AD}$ concentrations in the circulating blood with the other aforementioned parameters namely, BMI, waist circumference, blood pressure FBG and dyslipidemia. These results suggest that FBG and HDL-c significant association with AD. The FBG concentration had significant $(r=-2.91, \mathrm{P}<0.001)$ negative association with AD. Interestingly, there was strong \& positive association $(\mathrm{r}=2.89, \mathrm{P}<0.001)$ of HDL-c with AD.

Table 2. Socio-demographic Profile of Respondents

\begin{tabular}{|c|c|c|c|c|c|}
\hline Parameters & $\begin{array}{c}\text { Metabolic } \\
\text { Syndrome } \\
\text { n=76 (\%) }\end{array}$ & Mean \pm SE & $\begin{array}{c}\text { Non Metabolic } \\
\text { Syndrome } \\
\text { n=76 (\%) }\end{array}$ & Mean \pm SE & $\begin{array}{c}\text { Significance } \\
\text { Level }\end{array}$ \\
\hline Age & $54(10)$ & $53.97 \pm 1.15$ & $48(12)$ & $48.29 \pm 1.38$ & $(\mathrm{P}<0.002$ \\
\hline Gender & & - & & & \\
\hline Male & $29(38.2)$ & & $35(46.1)$ & - & $\mathrm{P}<0.328$ \\
\hline Female & $47(61.8)$ & & 41(53.9) & & \\
\hline Race & & - & & & \\
\hline Malay & $70(92.1)$ & & 65(85.5) & - & $\mathrm{P}<0.868$ \\
\hline Non-Malay & $6(7.9)$ & & $11(14.5)$ & & \\
\hline Current Smoker & & - & & & \\
\hline Yes & $6(7.9)$ & & 28(36.8) & - & $\mathrm{P}<0.000$ \\
\hline No & $70(92.1)$ & & $48(63.2)$ & & \\
\hline
\end{tabular}

NS=Non Significant.

Table 3. Anthropometric/Clinical Assessment of the Respondents

\begin{tabular}{lcc} 
& Table 3. Anthropometric/Clinical Assessment of the Respondents & \multicolumn{2}{c}{$\begin{array}{c}\text { Non-MetabolicSyndrome } \\
\text { (n=76) }\end{array}$} & $\begin{array}{c}\text { Significance Level } \\
\text { (P) }\end{array}$ \\
\hline Parameters & $\begin{array}{c}\text { Metabolic Syndrome } \\
(\mathbf{n}=76)\end{array}$ & $22.48 \pm 3.94$ \\
WC (cm) & $31.32 \pm 5.58$ & $75.1 \pm 9.5$ \\
Systolic BP (mmHg) & $101.8 \pm 10.1$ & $120 \pm 23$ \\
Diastolic BP (mmHg) & $138 \pm 16$ & 0.000 \\
\hline
\end{tabular}

$\mathrm{N}=$ Number of Respondents

Table 4. Biochemical Assessment of the Respondents

\begin{tabular}{lcc}
\hline \multicolumn{1}{c}{ Parameters } & $\begin{array}{c}\text { Metabolic Syndrome } \\
(\mathbf{n = 7 6 )}\end{array}$ & $\begin{array}{c}\text { Non Metabolic Syndrome } \\
(\mathbf{n = 7 6 )}\end{array}$ \\
\hline FBG (mmole/l) & $7.0 \pm 2.5$ & $4.7 \pm 1.4$ \\
TC (mmoles/l) & $5.39 \pm 0.99$ & $5.33 \pm 1.11$ \\
HDL-c(mmoles/l) & $1.22 \pm 0.35$ & 0.000 \\
LDL-c(mmoles/l) & $3.51 \pm 0.98$ & 0.757 \\
Triglyceride(mmoles/l) & $1.53 \pm 0.89$ & $3.53 \pm 1.11$ \\
Adiponectin(mmoles/l) & $11.64 \pm 4.26)$ & $1.07 \pm 0.99$ \\
\hline N & & 0.000 \\
\hline
\end{tabular}

$\mathrm{N}=$ Number of Respondents

\section{Discussion}

As mentioned earlier, that the anthropometric indices namely BMI and WC were significantly $(\mathrm{P}<0.001)$ lower in the Non-MS respondents compared to MS respondents. Similarly, the blood pressure both systolic and diastolic were significantly $(\mathrm{P}<0.001)$ lower in the Non-MS respondents compared to MS respondents. The correlation analysis reveals that weight height, WC and BMI are important indicators of MS maintaining normal BMI would increase adiponectin (Table 5). The FBG concentration was significantly $(\mathrm{P}<0.01)$ higher in $\mathrm{MS}$ respondents and surprisingly the TC \& LDL-c were not different. However, there seems to be a varied ratio of the cholesterol fractions particulary, HDL-c. Triglyceride concentration in the circulation seems to be also was also higher in MS respondents. The present study might be of greater interest to the clinician/physicians working in this particular area of research and treatment of MS patients. When the blood sample were assessed for AD it appears to be significantly $(\mathrm{P}<0.05)$ higher in the Non-MS 
respondents than the MS respondents. The comparison was made by using an independent t-test of the $\mathrm{AD}$ concentration gender and smoking status. These results suggest that gender and smoking status does not have an effect on serum adiponectin level. The observed correlation $(r=-2.91, \mathrm{P}<0.001) \&(r=2.89, \mathrm{P}<0.001)$ FBG and HDL-c with AD indicates that in these MS patients it is one of the important determinants. The hypoadiponectinemia has previously been reported to be existed in the MS patients [10,11,35] and in the present study on the Malaysian population is no exception. Some other studies have also indicated that hypoadiponectinemia exhibits hyperglycemia [11,17,18,19] and low HDLcholesterol [20] in MS patients. This means that there will be an increase in FBG with a negative association with $\mathrm{AD}$, while a decrease in HDL-c with a positive association with $\mathrm{AD}$ in MS patients. The present study suggests that BMI and Waist circumference are important differentiating factors in the MS patients. In a multivariate regression model, significant independent associations have been noted for age (positive), gender (men higher than women), race or ethnicity (race), educational status (inverse), hypercholesterolemia (positive), concentrations of Creactive protein (positive), physical activity (inverse), microalbuminuria (positive), and hyperinsulinemia (positive) [37]. However, they are not same in this population like gender, and hypercholesterolaemia. Adiponectin is suggested because of the mechanisms that it is involved in the signaling pathways that mediate the metabolic effects. It activate 5'-AMP-activated protein kinase (AMPK), stimulates phosphorylation of acetyl coenzyme A carboxylase (ACC), fatty-acid oxidation, glucose uptake and lactate production in myocytes, phosphorylation of ACC and reduction of molecules involved in gluconeogenesis in the liver, and reduction of glucose levels in vivo thereby directly regulating glucose metabolism and insulin sensitivity [38]. The present study might be an important step towards the assessment of MS prediction in patients by making use of anthropometry lipid profile.

Table 5. Pearson Correlation Analysis of Adiponectin with the MS Factors

\begin{tabular}{lcclcc}
\hline \multicolumn{1}{c}{ Parameters } & r-value & Sig. Level & Parameters & r-value & -0.291 \\
Weight & -0.232 & 0.004 & FBG (mmole/l) & 0.000 & 0.058 \\
Height & -0.201 & 0.013 & TC (mmoles/l) & 0.476 & 0.289 \\
BMI & -0.167 & 0.040 & HDL-c(mmoles/l) & 0.011 \\
WC (cm) & -0.225 & 0.005 & LDL-c(mmoles/l) & -0.148 \\
Systolic BP (mmHg) & -0.002 & 0.983 & Triglyceride(mmoles/l) & 0.299 \\
Diastolic BP (mmHg) & -0.046 & NS & & \\
\hline
\end{tabular}

NS=Non Significant

$*=\mathrm{P}<0.05, * *=\mathrm{P}<0.01, * * *<0.001)$.

\section{Conclusion}

The sample size of the present study was very small and is surely not the representative of the whole country and has to be concluded with great caution. However, it does suggest that the adiponectin and fasting blood glucose \& high density lipoprotein cholesterol concentrations can be used as predicators in the clinical assessments of metabolic syndrome apart from the parameters listed but still adiponectin is not an easily available option.

\section{Acknowledgement}

We would like to acknowledge to International Islamic University Malaysia (IIUM) for funding this study. We also would like to thanks to Director, Ministry of Health Malaysia and public health clinics in Kuantan for their cooperation and involvement in data collection process in this study.

\section{References}

[1] Third report of The National Cholesterol Education Program (NCEP) expert panel on detection, evaluation and treatment of high blood cholesterol in adults (Adult Treatment Panel III). Final Report. Circul 106: 3143-32441, 2002.

[2] Rosario S, Tiziana D C, Christiano A, Salvatore C, Giuseppe L. Hypoadinectinemia: A link between visceral obesity and metabolic syndrome. J Diabetes and Endocrinol 1: 27-35, (2010).

[3] Grundy SM. Hypertriglyceridemia, insulin resistance, and the metabolic syndrome. The Am J Cardiol 83: 25F-29F, 1999.
[4] Kissebah AH, Vydelingum N, Murray R, Evans DJ, Hartz AJ, Kalkhoff RK, Adams PW. Relation of body fat distribution to metabolic complications of obesity. J Clin Endocrinol and Metab 54: 254-260, 1982.

[5] Fujioka S, Matsuzawa Y, Tokunaga K, Tarui S.. Contribution of intra-abdominal fat accumulation to the impairment of glucose and lipid metabolism in human obesity. Metabol 36: 54-59, 1987.

[6] Nakamura T, Tokunaga K, Shimomura I, Nishida M, Yoshida S, Kotani $\mathrm{K}$, Islam A $\mathrm{H}$, Keno $\mathrm{Y}$, Kobatake $\mathrm{T}$ and Nagai $\mathrm{Y}$. Contribution of visceral fat accumulation to the development of coronary artery disease in non-obese men. Atherosclerosis 107: 239-246, 1994.

[7] Friedman JM, Halaas JL. Leptin and the regulation of body weight in mammals. Nature 395: 763-770, 1998.

[8] Hotmisligli GS, Arner P, Caro JF, Spiegelman BM. Increased adipose tissue expression of tumor necrosis factor- $\alpha$ in human obesity and insulin resistance. J Clin Invest 95: 2409-2415, 1995.

[9] Shimomura I, Funahashi T, Takahashi M, Maeda K, Kotani K, Nakamura T, Yamashita S, Miura M, Fukuda Y, Takemura K, Tokunaga K, Matsuzawa Y. Enhanced expression of PAI-1 in visceral fat: Possible contributor to vascular disease in obesity. Nature Med 2: 800-803, 1996.

[10] Mohan V, Deepa R, Pradeepa R, Vimaleswaran KS, Mohan A, Velmurugan K, Radha V. Association of low adiponectin levels with the metabolic syndrome-the Chennai Urban rural Epidemiology Study. Metabol 54: 476-481, 2005.

[11] Choi KM, Lee J, Lee KW, Seo JA, Oh JH, Kim SG, Kim NH, Choi DS, Baik SH. Serum adiponectin concentrations predict the developments of type 2 diabetes and the metabolic syndrome in elderly Koreans. Clin. Endocrinol 61: 75-80, 2004.

[12] Ryo M, Nakamura T, Kihara S, Kumada M, Shibazaki S, Takahashi M, Nagai M, Matsuzawa Y, Funahashi T. Adiponectin as a Biomarker of the Metabolic Syndrome. Circ J 68: 975-981, 2004.

[13] Matsushita K, Yatsuya H, Tamakoshi K, Wada K, Otsuka R, Takefuji S, Sugiura K, Kondo T, Murohara T, Toyoshima H.. Comparison of circulating Adiponectin and Proinflammatory markers regarding their association with metabolic syndrome in Japanese Men. Arterioscler Thromb Vasc Biol 26: 871-876, 2006. 
[14] Engeli S, Feldpausch M, Gorzelniak K, Hartwig F, Heintze U, Janke J, Möhlig M, Pfeiffer AF, Luft FC, Sharma AM. Association between adiponectin and mediators of inflammation in obese women. Diabetes 52: 942-947, 2003.

[15] Weyer C, Funahashi T, Tanaka S, Hotta K, Matsuzawa Y, Pratley RE, Tataranni PA.. Hypoadiponectinemia in obesity and type 2 diabetes: close association with insulin resistance and hyperinsulinemia. J Clin Endocrinol Metab. 86:1930-1935, 2001.

[16] Hotta K, Funahashi T, Arita Y, Takahashi M, Matsuda M, Okamoto Y, Iwahashi H, Kuriyama H, Ouchi N, Maeda K, Nishida M, Kihara S, Sakai N, Nakajima T, Hasegawa K, Muraguchi M, Ohmoto Y, Nakamura T, Yamashita S, Hanafusa T, Matsuzawa Y. Plasma concentrations of a novel, adipose-specific protein, adiponectin, in type 2 diabetic patients. Arterioscler Thromb Vasc Biol 20: 1595-1599, 2000.

[17] Krakoff J, Funahashi T, Stehouwer CD, Schalkwijk CG, Tanaka S, Matsuzawa Y, Kobes S, Tataranni PA, Hanson RL, Knowler WC, Lindsay RS. Inflammatory Markers, Adiponectin and Risk of Type 2 Diabetes in the Pima Indian. Diabetes Care 26: 1745-1751, 2003.

[18] Lindsay RS, Funahashi T, Hanson RL, Matsuzawa Y, Tanaka S, Tataranni PA, Knowler WC, Krakoff J. Adiponectin and development of type 2 diabetes in the Pima Indian population. Lancet 360: 57-58, 2002.

[19] Snehalatha C, Mukesh B, Simon M, Viswanathan V, Haffner SM, Ramachandran A. Plasma adiponectin is an independent predictor of type 2 diabetes in Asian Indians. Diabetes Care 26: 3226-3229, 2003.

[20] Matsubara M, Maruoka S, Katayose S. Decreased plasma adiponectin concentrations in women with dyslipidemia. J Clin Endocrinol Metab 87: 2764-2769, 2002.

[21] Zoccali C, Mallamaci F, Tripepi G, Benedetto FA, Cutrupi S, Parlongo S, Malatino LS, Bonanno G, Seminara G, Rapisarda F, Fatuzzo P, Buemi M, Nicocia G, Tanaka S, Ouchi N, Kihara S, Funahashi T, Matsuzawa Y. Adiponectin, metabolic risk factors, and cardiovascular events among patients with end-stage renal disease. J Am Soc Nephrol 13:134-141, 2002.

[22] Yang WS, Lee WJ, Funahashi T, Tanaka S, Matsuzawa Y, Chao CL, Chen CL, Tai TY, Chuang LM. Weight reduction increases plasma levels of an adipose-derived anti-inflammatory protein, adiponectin. J Clin Endocrinol Metab 86:3815-3819, 2001.

[23] Yang WS, Jeng CY, Wu TJ, Tanaka S, Funahashi T, Matsuzawa Y, Wang JP, Chen CL, Tai TY, Chuang LM. Synthetic peroxisome proliferator-activated receptor-_ agonist, rosiglitazone, increases plasma levels of adiponectin in type 2 diabetic patients. Diabetes Care 25:376-380, 2002.

[24] Maeda N, Shimomura I, Kishida K, Nishizawa H, Matsuda M, Nagaretani H, Furuyama N, Kondo H, Takahashi M, Arita Y, Komuro R, Ouchi N, Kihara S, Tochino Y, Okutomi K, Horie M, Takeda S, Aoyama T, Funahashi T, Matsuzawa Y.Diet-induced insulin resistance in mice lacking adiponectin/ ACRP30. Nat Med 8:731-737, 2002.

[25] Yamauchi T, Kamon J, Waki H, Terauchi Y, Kubota N, Hara K, Mori Y, Ide T, Murakami K, Tsuboyama-Kasaoka N, Ezaki O, Akanuma Y, Gavrilova O, Vinson C, Reitman ML, Kagechika H, Shudo K, Yoda M, Nakano Y, Tobe K, Nagai R, Kimura S, Tomita M, Froguel P, Kadowaki T. The fat-derived hormone adiponectin reverses insulin resistance associated with lipoatrophy and obesity. Nat Med. 7:941-946, 2001.

[26] Fruebis J, Tsao TS, Javorschi S, Ebbets-Reed D, Erickson MR, Yen FT, Bihain BE, Lodish HF. Proteolytic cleavage product of 30-kDa adipocyte complement-related protein increases fatty acid oxidation in muscle and causes weight loss in mice. Proc Natl Acad Sci 98:2005-2010, 2001.

[27] State/District Data Bank,Malaysia, Department of Statistics, Malaysia, 2012. statistics.gov.my/portal/download.../Bank_Data_Negeri_Daerah20 12.pdf. (Accessed on September 2, 2014).

[28] Alberti KG, Zimmet P, Shaw J. The metabolic syndrome. A new worldwide definition. Lancet. 366: 1059-1062, 2005.

[29] Lwanga, S.K and Lemeshow S. Sample size determination in health studies: A practical manual. WHO, Geneva, 1991.

[30] Gil-Campos M, Canete R, Gil A. Adiponectin, the missing link in insulin resistance and obesity. Clin Nutr 23: 963-974, 2004.

[31] Hotta K, Funahashi T, Arita Y. Plasma concentration of a novel, adipose-specific protein, adiponectin, in type 2 diabetic patients. Arterioscl Thromb Vasc Biol 20: 1595-1599, 2000.

[32] Rosario S, Tiziana DC, Christiano A, Argano C, Corrao S, Licata G. Hypoadinectinemia: A link between visceral obesity and metabolic syndrome. J Diabetes and Endocrinol 1: 27-35, 2010.

[33] Matsuzawa Y. The metabolic syndrome and adipocytokines. FEBS 580: 2917-2921, 2006.

[34] Ouchi N, Kihara S, Arita Y, Okamoto Y, Maeda K, Kuriyama H, Hotta K, Nishida M, Takahashi M, Muraguchi M, Ohmoto Y, Nakamura T, Yamashita S, Funahashi T, Matsuzawa Y. Adiponectin as adipocyte-derived plasma protein, inhibits endothelial NF-kappa B signaling through a cAMP-dependent pathway. Circ 102:1296-1301, 2000.

[35] Ryo M, Nakamura T, Kihara S, Kumada M, Shibazaki S, Takahashi M, Nagai M, Matsuzawa Y, Funahashi T. Adiponectin as a biomarker of the metabolic syndrome. Circ 68: 975-981, 2004

[36] WHO. World Health Organization definition of health. www.who.int/about/definition/en/print.html (Accessed on 30th July, 2014).

[37] Ford, ES, Chaoyang LI and Guixiang ZHAO. Prevalence and correlates of metabolic syndrome based on a harmonious definition among adults in the US. J Diabetes 2:180-193, 2010.

[38] Yamauchi T, Kamon J, Minokoshi Y, et al. Adiponectin stimulates glucose utilization and fatty-acid oxidation by activating AMPactivated protein kinase. Nat Med 8: 1288-95, 2002. 